\title{
English and European Languages are Arabic Dialects on the Loose: The Evidence: "The Emperor Marries Mary Merrily on a Mare by the Mere": A Consonantal Radical Theory Approach
}

\author{
Zaidan Ali Jassem* \\ Department of English Language and Translation, Qassim University, KSA
}

*Corresponding Author: Zaidan Ali Jassem, Department of English Language and Translation, Qassim University, KSA

\begin{abstract}
This paper sets out to establish the status of English, German, French, Latin, Greek, and Sanskrit as Arabic dialects. In particular, it examines a number of words (36) with the common consonantal radicals or roots $m(p)--r$ in words like imperial and its derivatives such as emperor, empire, imperial, imperative, and formally similar but semantically different words like marry, merry, Murray (Moray), mare, mayor, mar, mere, merely, marine, more, mirror, admire, moor from a consonantal radical or lexical root theory perspective. The data consists of around 30 such words, making up the title sentence above and many others. The results clearly show that all such related words have true Arabic cognates, with the same or similar forms (i.e., m---r $\square \square \square$ P ) and meanings whose different forms, however, are all found to be due to natural and plausible causes and different courses of linguistic change. Furthermore, they exhibit the failure of English and European historical lexicography and linguistics in manifesting the close genetic relationships between Arabic and such languages. As a consequence, the results indicate, contrary to traditionally longheld Comparative Method and Family-Tree Model claims, that Arabic, English, and all the so-called IndoEuropean languages belong to the same language, let alone the same family. Therefore, they prove the adequacy of the consonantal radical theory in relating Indo-European languages to Arabic as their origin all because, unlike any other language in the group, it shares really living, not fictitious, cognates with all of them.
\end{abstract}

Keywords: M(P)--R-Based Word Roots, Arabic, English, German, French, Russian, Latin, Greek, Sanskrit, Lexicography, Historical Linguistics, Consonantal Radical/Lexical Root Theory

\section{INTRODUCTION}

Thus far, 58 papers have firmly established the close genetic relationship between Arabic and the socalled Indo-European languages, covering all aspects of language analysis phonetically, morphologically, grammatically, and lexically or semantically (Jassem 2012-2018). In all those papers, words have been classified into (a) broad semantic fields or areas such as family terms, animal terms, colour terms, religious/divine terms or (b) grammatical functions and categories like pronouns, question words, verb to be, and the like. The purpose of all these papers is to reject traditional thinking and practice as well as long-held views in the field which classifies Arabic and IndoEuropean languages like English, German, French, Latin, Greek, and so on as members of different families (Bergs and Brinton 2012; Algeo 2010; Crystal 2010: 302; Campbell 2013; Yule 2006; Crowley 1997: 22-25, 110-111; Pyles and Algeo 1993: 61-94).

Like its predecessor (Jassem 2018d), this paper tries to focus more closely on fewer terms or word roots of two types: (i) those that are similar in form and meaning but have different spellings and pronunciations which are listed in separate entries in English and Indo-European lexicography and linguistics like emperor, empire, imperative, imperial, mayor, umpire, and (ii) those that are formally similar but semantically different words like marry, merry, Murray (Moray), mare, mayor, mar, mere, merely, marine, more, mirror, admire, moor, most of which have separate entries in the dictionary which should, as a matter of fact, be listed under one root as is the case in Arabic dictionaries. Again, this work, just like Jassem (2018d), has three aims: First, it focuses on fewer words which are more beneficial to the reader who does not have either the time or patience to go through long lists of words in a basically glossary-type work, since using fewer related words is easier to handle, faster to 
English and European Languages are Arabic Dialects on the Loose: The Evidence: "The Emperor Marries Mary Merrily on a Mare by the Mere": A Consonantal Radical Theory Approach

complete, clearer to understand, and more useful or manageable to grapple with or apply. Secondly, it shows the failure of Western linguists and lexicographers and their faulty analyses because the descriptions of all European languages were all initially modeled on Latin. Finally, just like all other papers (Jassem 2012-2018), it tries to link all those languages successfully to Arabic which is their end origin all.

The paper has four sections: introduction, research methods, results, and conclusion.

\section{RESEARCH METHODS}

\subsection{The Data}

The data consists of 36 words or so which have the common consonantal radicals or roots $m(p)-r$ as in imperial, emperor, empire, imperative, and formally similar but semantically different words like marry, merry, Murray (Moray), mare, mayor, mar, mere, merely, marine, more, mirror, admire, moor, and so on. More precisely, the data comprises three such sets: the first set contains those words with the general meaning of 'rule, authority, power', including imperial, emperor, empire, imperative; the second is a subset, including mayor and umpire; the last set contains formally similar but semantically different words like marry, merry, mare, Murray, mar, mere, merely, marine, more, mirror, admire, and moor. All these words can be combined to form various sentence types such as The emperor marries Mary merrily on a mare by the mere; the mayor/umpire marries Mary merrily on a mare by the mere in the empire; the merry emperor mars Mary's marriage to the mayor; etc. Their selection has been primarily based on their formal similarity in having the consonants $m(p)-r$ and semantic difference, which can all be traced back quite easily to Arabic cognates with the same or similar forms and meanings as shall be seen in Section 3 below.

The etymological data for English and Indo-European languages is based on Harper (2012-18) and his sources. For Arabic, the meanings are taken from Ibn Manzoor (2018) in the main and related edictionaries like Albaheth Alarabi (2018) and Almaany.com (2018) in addition to my own knowledge of Arabic as a native speaker. The Arabic cognates of the above English and Indo-European words are exclusively mine, though.

In transcribing the data, normal spelling is used for practical purposes. However, certain symbols were used for unique Arabic sounds, including $/ 2 \tau \& 3 \varepsilon /$ for the voiceless and voiced pharyngeal fricatives respectively, /kh $\dot{\tau} \&$ gh $\dot{\xi}$ / for the voiceless and voiced velar fricatives each, capital letters

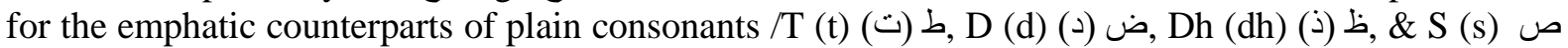
(س)/, and /" \&/ for the glottal stop (Jassem 2013c). Long vowels are doubled, e.g., /aa, oo, \& ee/.

\subsection{Data Analysis}

\subsubsection{Theoretical Framework: Consonantal Radical/Lexical Root Theory}

Data analysis utilizes the consonantal radical theory, which is a more precise version of the lexical root or radical linguistic theory (Jassem 2012a-14e). The name derives from the use of consonantal radicals or, more generally, lexical roots in examining genetic relationships between words such as the derivation of observation from serve (or simply srv), description from scribe (or simply scrb), writing from write (or simply wrt). The main reason stems from the fact that the consonantal root carries and determines the basic meaning of the word regardless of its affixation such as observation. As to vowels, they are neglected because they show mainly phonetic and grammatical relationships and functions as in English sing (inf.), sang (past), sung (p.p.), song (n), and Arabic qaal (v) 'to say'

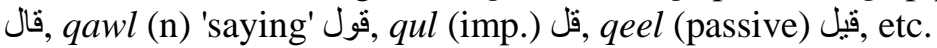

A full exposition of the lexical root theory and procedures can be found in Jassem (2018b) which will be skipped over here to save time, effort, and space. However, the main procedures of analysis in relating, e.g., English and Arabic words to each other genetically can be summed up in five steps as follows.

- Select any word, starting with consonantal roots and overlooking vowels, e.g., the, imperial, marry, mare, mere.

- Identify the source, daughter, or sister language meaning (e.g., English, Latin) on the basis of especially word history or etymology. It is essential to start with word root meanings, not sounds 
as the former are more stable and change a lot less than the latter which do so extensively and drastically; for example, all the sounds of a given word might change beyond recognition while meanings in a rather limited way, The meaning first approach will often lead the analyst to the correct cognate naturally whereas the sounds first will lead them nowhere definitely.

- Search for the word with the equivalent meaning and form in the target, parent, or reference language (e.g., Arabic), looking for cognates: i.e., sister words with the same or similar forms and meanings.

- Explain the differences, if any, in both form and meaning between the cognates lexicologically, phonetically, morphologically, and semantically as indicated. As a matter of fact, finding the right cognate on the basis of its meaning first often leads one to the resultant changes automatically.

- Finally, formulate phonological, morphological, grammatical, and semantic rules after sufficient data has been amassed and analyzed.

That is the whole story simply and briefly. Section 3 illustrates that step by step.

\subsubsection{Statistical Analysis}

The percentage formula is used for calculating the ratio of cognate words or shared vocabulary, which is obtained by dividing the number of cognates over the total number of investigated words multiplied by a 100 . For example, suppose the total number of investigated words is 100 , of which 90 are true cognates. The percentage of cognates is calculated thus: $90 / 100=9 \times 100=90 \%$. Finally, the results are checked against Cowley's (1997: 173, 182) formula to determine whether such words belong to the same language or family (for a survey, see Jassem 2012a-b).

\section{RESULTS AND DISCUSSION}

The main focus of the results will be on the Arabic consonantal radicals or lexical roots of English, German, French, Latin, Greek, and Indo-European words and affixes (prefixes, infixes, and suffixes); vowels will be generally overlooked whose main function is phonetico-grammatical rather than semantic as has been stated above.

As to the first set, which is comprised of those words with the general meaning of 'rule, authority, power', including imperial, emperor, empire, imperative and the second subset of mayor and umpire, all such words derive from true Arabic roots or cognates with the same or similar forms $(m-r)$ and meanings (rule, authority), as follows.

Empire has many derivatives like emperor, imperial, imperialism, imperialist, imperative, imperator, (umpire, mayor), which came from Old French empire, from Latin imperium 'rule, command, authority, power, dominion', from emperare (v) 'command', from (i) en 'in' + (ii) parare 'order, prepare', from PIE root *pere- (1) 'to produce, procure', which is not true anyway because it is too partitive or divisive. Alternatively, it comes straight from Arabic 'imara(t) (n) 'emirate, princedom' إمارة, from 'amr (n) 'rule, command, order' أمرة, from 'amar (v) 'to command, order' أمر; /p/ was inserted or split from $/ \mathrm{m} /$. Thus, the Arabic cognate is straight, short, and logical.

All the derivatives and suffixes have true, identical Arabic cognates as follows.

Emperor came from French empereur, from Latin imperiator 'commander, emperor', from emperare (v) 'command', ultimately from Arabic 'ameer 'ruler, prince' أمير, amar (v) 'to command, order' أمر ; /p/ was inserted or split from $/ \mathrm{m} /$.

As to the noun suffix -or, it is actually a lexically or morphologically conditioned variant of -an as in American, republican, both ultimately from Arabic - an itself as in kaslaan 'lazy' كسلان, from kasal (n) 'laziness' كسل (for details, Jassem 2012f, 2013a).

Imperial (imperialism, imperialist; emirate, emir) came from French empereur, from Latin imperiator 'commander, emperor', from emperare (v) 'command' above, directly from Arabic alameer 'the prince, ruler' الأمير via reordering and /p/-insertion. That is, the derivational suffix -al derives from the Arabic definite article prefix al- الـ via morphological shift (see Jassem 2013a).

What about formally similar but semantically different empirical (empiricist)? Again, it derives from Arabic. More precisely, it came from Latin empiricus 'a physician guided by experience', from Greek 
empeirikos 'experienced', from empeiria 'experience/practice without knowledge', from empeiros 'experienced in a thing, proven by use', from (i) in (en-) and (ii) peira 'trial, experiment', from PIE root *per-ya-, suffixed root of *per- 'to try, risk', which is unnecessarily too long and inaccurate. Instead, it comes ultimately and directly from Arabic:

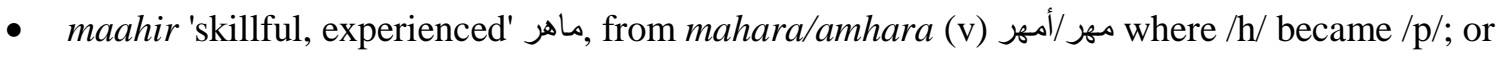

- baari3 (adj./n.) 'the one who excels in something' from bara3 (v) 'to excel in something' برع ع via /3/-loss and semantic shift, which is less likely.

As to the affixes en-/em-, -ic, and -al, all have been dealt with and traced back to Arabic (see above and below).

\section{Imperialist}

As to the suffix -ist, it comes straight from Arabic ist- (e.g., istaqbal (v) 'to receive someone' استقبل, from qabal (v) 'to accept' قبل via morphological shift or - at 'derivational and inflectional affix' coupled with its split into /-st/ (e.g., kaatib (masc. suf.) 'male writer' kaatibat (fem. suf.) 'female writer' كاتبة via morphological shift (see Jassem 2012f, 2013a).

\section{Imperialism}

Regarding the suffix -ism, it derives direct from Arabic mus(t)- (e.g., mustaqbil (n./adj.) 'receiver', mustaqbal (n./adj.) 'future' مستقبل, from qabal (v) 'to accept' via reordering or reversal and morphological shift (see Jassem 2013a).

Imperative came from Old French imperatif, from Latin imperativus 'pertaining to a command', from imperat-, past participle stem of imperare (v) 'command' above, directly from Arabic 'imrat 'command, authority' إمرة via/p/-insertion. So it has three morphemes: imper-, -at-, \& -ive, the last two of which are from Arabic - at 'derivational and inflectional affix' which became /-ve/ coupled with morphological shift (see Jassem 2012f, 2013a).

As regards the second subset mayor, umpire, they are related in meaning and form to empire above, although they are wrongly derived from different etymological roots as follows.

Mayor (mayorette, mayoralty) descended from French, from Latin maior, major, (irregular) comparative of magnus 'great', which is etymologically wrong anyway. More precisely, it (magnus) might have descended from Arabic:

- majeed 'great' مجيد where /j \& d/ became /g \& n/;

- jamm 'much' جi via reordering; or

- majmoo3(at) 'group; gathered; big; total' (a) vجموع via /3/-loss and turning /m/ into /n (Ø)/.

However, that is not an accurate origin. Alternatively, it comes, in my view, directly from Arabic 'ameer, 'umayer (dim.) 'prince, commander' أمير. Thus, the Arabic cognate 'ameer split into two words (mayor \& emperor) in English and European languages- a clear case of lexical split. (See more, many, much, most below.)

The suffixes -ette and -ty are morphologically conditioned variants, both which come from the above-mentioned Arabic - at 'inflectional and derivational affix' while -al is from Arabic al- 'the' via morphological shift.

Majority (major) is inaccurately related to mayor in origin, which came from Old French, from Latin majoritas 'majority', from maior, comparative of magnus 'large, great', which has been settled under mayor above; in my view, it alternatively derives from Arabic:

- jamhoor(iat) 'majority' (a) جمهوريـ via reordering and /h/-loss; or

- ' ' أمرة 'amarat 'increase, plenty, growthich is the likeliest (see more below).

Umpire came from Old French enonper 'odd number, not even', from (i) enon 'not', direct from Arabic 'in/'an 'not' إن (jassem 2013b, 2018b) and (ii) per 'equal', from Latin par 'equal', of unknown origin, or perhaps from PIE root *pere- 'to grant, allot', direct from Arabic barra, abarra 'to give, to 
English and European Languages are Arabic Dialects on the Loose: The Evidence: "The Emperor Marries Mary Merrily on a Mare by the Mere": A Consonantal Radical Theory Approach

grant, to be kind and generous' بر، أبر which is wrong anyway despite its Arabic cognate as well. Instead, it comes again straight from Arabic 'ameer 'ruler, commander' أمير', from 'amar (v) 'to command, order' أمر via /p/-insertion or split from /m/.

As can be clearly seen, empire, mayor, and umpire are all taken from one Arabic cognate- 'ameer أمير,, which split into three different words. That is, these are lexically conditioned variants due to lexical split. In summary, all these words in Arabic and English and European languages share the same or similar meaning of 'authority and power' and form $/ \mathrm{m}-\mathrm{r} / \mathrm{with} / \mathrm{p} /$ being an insertion in the latter.

Now, we turn to the third set and their Arabic cognates, which includes formally similar ( $m-r$-based) but semantically different words like marry, merry, Murray, mare, mayor, mar, mere, merely, marine, more, mirror, admire, and moor.

Marry has many derivatives such as marriage, marital, matrimony, matron, mother, all of which have identical Arabic cognates, which are the same or similar in form and meaning. They all came from Latin maritus 'husband', from maritare (v) 'to marry', from PIE root *mari 'woman', ultimately from Arabic mar'a(t) (pronounced mara in the vernacular) 'woman, wife' مر أة via lexical shift (Jassem 2013k). Thus, unlike PIE, the Arabic cognate is real, living, and original, not fictitious or hypothetical.

As to the suffixes of the derived forms or words, they all have identical Arabic cognates as well, which are as follows.

Marriage has two morphemes: (i) mari-above + (ii) -age, where the latter is from Arabic -ee 'a derivational and inflectional suffix' to which $-j$ was added as was common in some olden Arabic dialects as well as today's southern Saudi (Tamimi) Arabic in Jizan and Najran in which -ee-final words attached $-j$ as in 3arabi $\rightarrow$ 3arabij 'Arabic' عربي/عربيج, adabi $\rightarrow$ adabij 'literary' أدبي/أدبيج. In some modern Arabic accents like Kuwaiti and UAE Arabic, /j/ is replaced by /ee (y)/ such as jamal $\rightarrow$ yamal 'camel' جمل/يمل and faraj $\rightarrow$ farai 'free, happy; a proper name' فرج، فري.

Marital is from Arabic almar'at ' the woman' المرأة to which reordering and morphological and semantic shift applied. That is, marital has three morphemes: mari- $+-t+-a l$, where $-t$ is from Arabic $-t$ ' fem. suf.' ت تـ while - al from Arabic al- 'the' الـ via morphological shift (Jassem 2016d).

Matrimony (matron) is another derivative whose suffixes - mony and -on can be considered variants, both of which came directly from Arabic - un 'inflectional and derivational suffix' ن- ن which split into $/ \mathrm{m} \& \mathrm{n} /$ in -mony coupled with morphological shift (Jassem 2012f, 2013b, 2016a). Alternatively, it comes from the Arabic adjectival prefix mun- sia morphological shift as in mundathir 'obsolete' مندثر, from indathar اندثر, from dathar 'to die out' In other words, matron is Arabic mar'atun 'a woman (nom. indef.)' مرأ 'أنر via reordering and morphological shift.

Maternity (matron) is another derivative whose suffixes $-n$ and -ity came directly from Arabic $-n$ 'inflectional and derivational suffix' - and -ta/-at 'inflectional and derivational suffix' تـ/ (Jassem 2012f, 2013b, 2016a).

Mother (maternal, maternity, matrimony, matrix) came from German Mutter, Latin mater, (Italian matre, Spanish madre, French mere), Greek meter, Sanskrit matar, all ultimately from Arabic mar'a(t) 'woman, wife' مر above to which reordering, turning /t/ into /dh (d)/, and semantic shift applied.

In European languages like French and German, similar forms or words are used which suffered different sound and semantic changes or shifts. More precisely, German Frau 'woman; wife', French mère 'mother', and Spanish mujera 'woman' all descended directly from Arabic mar'a(t) by substituting /f/ for / $\mathrm{m} /$ in German. Furthermore, French mari 'husband' is from Arabic mar', imri' 'man' via lexical shift (see Jassem 2016d). Even the definite articles, which usually accompany such nouns in all these languages like Romance (e.g., French le/la) and Germanic (e.g., German der/die/das, English the), have identical Arabic parent cognates.For example, French and Romance le/la are both from Arabic al- 'the' الـ; English and Germanic the (die, der, das), which originally meant 'this', are from Arabic dha/dhi 'this' ذي ذا/ذا to which morphological shift (i.e., grammaticalization) applied (see Jassem 2016d). 
On a more general plane, all English and Indo-European marriage-related terms such as sex, bigamy, wedding, engagement, and divorce (Jassem 2013k, 2013q, 2018d) have true Arabic cognates.

Mary (Marie, Marilyn, Marionette, Marian, Maria) is a very common name of Biblical origins in European tongues, which came from Old English Mari(a/e), Latin Maria, Greek Mariam, from Aramaic Maryam 'lit., rebellion' which is wrong in my view as it does not reflect or better match the holy status of Virgin Mary, the Mother of Jesus. Instead it derives direct from Arabic:

- mariam 'mother of the Prophet Jesus; a chaste, honourable woman who likes talking to men decently and without being vulgar' مريم;

- maraam 'desire, want, quest, goal; revenge in my dialect' مر ام, from raama (v) 'desire; of sheep, to love (lick and suckle) its baby lamb, after having ignored it for delivery pains for a while' رام (cf. raim 'addition, preference, favour, height, distance, deer, stay' via reversal ريم);

- maaria(t)'a white woman' ماري/مارية;

- 'amira(t) 'of women, blessed, kind, good' أمرة, from 'amira (v) 'to increase in wealth, children, kindness' أمر: or

- marmaara(t) 'a soft, shaking young girl' مرمارة.

Merry (mirth) shares /m \& r/ with marry, which comes from Old English myrge 'pleasing, pleasant, sweet', Middle Dutch megelijc 'joyful', from Proto-Germanic *murgijaz, which probably originally meant short-lasting' (cf. Old High German murg 'short'), from PIE root *mergh-u- 'short'), which is, in my view, a wrong or false cognate, semantically speaking. Instead, it ultimately derives from either Arabic:

- mari2 'merry' مرح via/2/-loss, which is the likeliest; or

- mari 'merry, delicious' مري.

Mar came from Old English merran, mierran 'to waste, spoil', from Proto-Germanic *marzjan (source of Old High German marren 'to hinder, obstruct', Gothic marzjan 'to hinder, offend'), from PIE root *mers- 'to trouble, confuse' (source of Sanskrit mrysate 'forgets, neglects', Lithuanian miršti 'to forget'), from Arabic:

- $\quad$ murr (marmar) 'bitter, to make bitter' مر ، مرمر via lexical shift;

- marr 'to pass; water, rain' s via lexical shift; or

- maara, mawr (n) 'to move, to come and go, to shake, to hesitate; opposition' مار ، مور via sense shift.

- maara 'to doubt' مارى via sense shift.

Mare has two senses 'horse, sea', both of which can be traced back to Arabic quite easily. More precisely, it descended from Old English mere, myre, fem. of mearh 'horse', from Proto-Germanic *markhjon- (Dutch merrie, Old High German German Meriha, German Mähre 'mare'), supposedly from Gaulish origin (cf. Irish and Gaelic marc, Welsh march, Breton marh 'horse'), all directly from Arabic muhr (m.), muhra(t) (f.) 'young or baby horse' مهر /مهرة via /h/-loss and reordering in old forms.

As to the other sense 'sea' as in mere below, it came from Latin mare 'sea', from PIE root *mori- 'body of water', direct from Arabic mar 'water, rain, sea' مر or mawr'sea wave' مور.

Mere (mare) means 'sea, ocean, lake, pool' and has several derivatives, including mire, marine, mariner, marinate, which came from Old English mere 'sea, ocean, lake, pool', from Proto-Germanic *mari (Dutch meer, German Meer 'sea'), from PIE root *mori- 'body of water', directly from Arabic:

- $\quad$ mar (marmara(t)) 'sea, much rain' مر، مرمرة;

- ' ' أمرار

- mawr 'sea wave' مور; or

- ba2r(at) 'sea' بحر، بحرة where /b \& 2/ changed to /m/ and Ø each, which is less likely (cf. mermaid from a reversed Arabic amat-(ul)-mar 'mermaid': i.e., mar 'sea' plus amat 'maid' أمة (c), turning $/ \mathrm{t} /$ into $/ \mathrm{d} /$.) 
Merely is a derivative, meaning 'purely', where -ly 'like' came from Old English lic, lice (adv.) 'shape, form', ultimately from Arabic shakl 'form, shape' شكل via reversal (i.e., laksh), merging /sk \& $\mathrm{k} /$ into /c/, then into /y/, and morphological shift (Jassem 2013a).

Marine (mariner, marinate, mere, mire) came from French, from Latin marinus 'of the sea', mare 'sea', from Arabic above.

As to the adjectival suffix -ine, it is from Arabic - an 'inflectional and derivational affix' (see Jassem 2013a).

Murray (Moray) is a mainly Scottish English proper name, meaning 'sea settlement; by the sea', from Latin moravia, from moreb. The first syllable murr-/mor- means 'sea, water' and derives from the same root for mere, mar 'sea', whose Arabic cognate has already been settled.

As to the second syllable -avia, -eb, it comes from Arabic bau', bee'a(t) بو ، بيئة, from bawa' 'to stay; dwell 'يوأ Also -ay, it is a place name suffix. Its Arabic cognate is -ee 'inflectional and derivational يasfix' يـ (Jassem 2013a).

More is an irregular comparative form, which came from Old English mara 'greater, stronger, mightier, more' (comparative of micel 'great') and German mehr 'more', from Arabic kaamil 'complete, whole' كامل or jamal, jumla(t), jameel 'amount; big, great; beautiful; camel' via reordering and turning /k (j)/ into /c/ جمل، جملة، جميل. However, although the above etymology can be successfully traced to Arabic, it is not accurate. Instead, it comes straight from Arabic:

- ' 'amir 'much; to increase' أمر,

- 'imr 'great, big' إمر,

- $\quad$ murr 'powerful, strong, bitter' $ر$, or

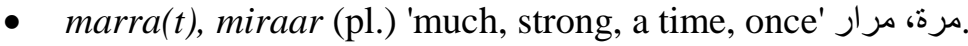

The first two are the likeliest, which come from the same Arabic root anyway 'amar أمر as in empire and its derivatives above.

As to many, much, most, they all come from Arabic cognates as well as can be clearly seen below.

Many (much, more, most) came from Old English monig/manig (adj.), menigu (n) 'many, much' and German manch 'many', menge (n) 'multitude, direct from Arabic majmoo3 'lit., gathered; many, total' مجموع, from jam3 (n) 'gathering, multitude', from jama3 (v) جمع 'gather' via reordering, /3/-loss and replacing $/ \mathrm{m} \& \mathrm{j} /$ by $/ \mathrm{n} \& \mathrm{~g}(\mathrm{y}) /$.

Much (many, more, most) came from Middle English muchel 'large, much', from Old English micel 'great in amount or extent', from Arabic:

- kaamil 'full, complete' كامل via reordering and turning /k/ into /c/ in Old English and into /ch/ later besides /l \& m/-merger;

- jamal, jumla(t), jameel, mujmal 'amount, total; big, great; beautiful; camel' جمل، جملة، جميل، مجمل via reordering and turning $/ \mathrm{j} /$ into $/ \mathrm{s} /$; or

- jamm 'much' جia reversal and turning /j/ into /ch/.

Mirror (mirage, admire, miracle) came from Old French mireoir 'looking glass, model, example', earlier miradoir (Spanish mirador, mirar (v)), from mirer 'look at oneself in a mirror; observe, watch', from Vulgar Latin mirare 'look at', from mirari 'wonder at, admire', directly from Arabic mir'a(t) 'mirror' مر آة, from marra 'to look in a mirror' (v) ر

Admire (admiration, mirror, mirage) is a compound of (i) ad 'to, with regard to' and (ii) mirari 'to wonder at' above, directly from Arabic tamarra (v) 'to look in a mirror; to admire' تمرى 'atamarra '(I) look in a mirror' أتمرى, from marra 'to look in a mirror' (v) مرى, from ra'a (v) 'to see' رأى, where /t/ became /d/ besides reordering. So the prefix $a d$-is from Arabic $t a$ - 'derivational and inflectional affix' - via reordering and passing /t/ into /d/, an analysis countering its wrong etymology above.

Admiral is an attested Arabic borrowing, derived from the same source for mer, mar (marine) above. It has three morphemes $a d-, m i-$, and $-a l$, all of which have already been accounted for. 
Miracle (miraculous) is a compound of Latin (i) mir- (mirari) 'to wonder at' above, directly from Arabic marra 'to look in a mirror' (v) مرى , from ra'a (v) 'to see' رأى, and (ii) -cle 'small', from Arabic qall, qaleel 'small, little' قل، قليل where /q/ became /k/.

Mirage is a compound of (i) mira-, from Latin mirari 'to wonder at' above, and (ii) -age 'nominal suffix', whose Arabic cognate has already been established.

Moor (mooring; moorland) has several senses, which came from Old English mor 'morass, swamp', from Proto-Germanic *mora- (source also of Dutch meer 'swamp', Old High German muor 'swamp, sea', German Moor 'moor', Old Norse morr 'moorland', marr 'sea'), from Arabic marr 'water' mar, mere, marine above. In addition, it may derive from Arabic:

- mar3a 'grazing ground, pasture' مرعى via /3/-loss;

- maraa2 'animals' den; water-filled area; washing, rinsing' مراح via /2/-loss (cf. mere above),

- mareer 'empty earth' مرير; or

- marwaraa(t) 'empty earth or desert' مروراة.

Myrrh (myrtle) is a well-known borrowing from Arabic murr, murrah/murra(t) (f.) 'bitter' مر.

Myrtle is from Greek myrtos 'the myrtle', from Arabic murr(ah) 'bitter'. More precisely, it has three morphemes: myr-, -t, -le, all of which are Arabic in origin, where the second (and Greek -os 'masc. suff.) are from Arabic - at 'derivational and inflectional affix' whereas the last is from Arabic al- 'the' via morphological shift. In other words, it comes from Arabic almurrat 'the bitter (one)' المرة via reordering.

Merit came from Old English merite 'wages, pay, reward; thanks, moral worth, that which assures divine pity', directly from Latin meritum 'a merit, service, kindness, benefit, favour', neuter of meritus, past participle of merere, meriri 'to earn, deserve, acquire, gain', from PIE root *(s)mer- (2) 'to get a share of something', direct from Arabic:

- ' ' 'amara(t) 'growth, increase, blessedness, goodness' أمرة:, from 'amira (v) 'to increase' أمر;

- 'imra(t) 'goodness, blessedness; an order to give something to someone' إمرة, from 'amar (v) 'order' أمر:; or

- muroo'a(t) 'male perfection; perfect morality; kindness, virtue' مروءة, from mari'a (v) 'to be perfect, happy' مر أ 'per.

Now after the above detailed analysis, we can turn back to the title sentence The emperor marries Mary merrily on a Mare by the mere, which can still be read and understood in today's Arabic as follows.

The emperor marries Mary merrily on a Mare by the mere

'dha ameer mara mari mara2 3an muhra bi dha marr'.

$$
\begin{aligned}
& \text { "ذا أمير مرة مارية مرح عن مهرة بذا مر ؛ = } \\
& \text { ذا الأمير (تزوج) امر أته مارية بمرح على مهرة بذا المر (الماء)." }
\end{aligned}
$$

In short, the words are all Arabic but the structure is different due to linguistic change over time. As to the definite article the, which originally meant 'this' in Old English, it derives from Arabic dha/dhi 'this' ذا/ذي although it underwent morphological change later (see Jassem 2016a). The inflectional morpheme $-s$ ' $3{ }^{\text {rd }}$ per. sing. pres. tense' in marries alternates with $-t$ in German and French which all came from the Arabic affix $-t$ (ta-/-at ت) 'inflectional and derivational morpheme' as has been shown above (see Jassem 2012f, 2013a, 2015d, 2016d).

To sum up, the total number of words with the roots $m-(p)-r$ amounted to 36 , all of which have true Arabic cognates. 


\section{CONCLUSION}

To conclude, the main findings of this paper were as follows:-

- The $m(p)--r$-based words in English and European languages like empire, imperial, umpire, mayor, marry, merry, Murray, mare, mar, mere, more, and so on all derive from true and identical, ultimate Arabic cognates or roots with the same form $m-r(r) / m h r \quad$ קر resultant differences resulted from natural and plausible causes and different routes of language change in each language.

- The findings lend further support to the adequacy of the consonantal radical theory, a more precise version of the lexical root or radical linguistic theory, in relating English and IndoEuropean words, roots, and affixes to Arabic from which they arose for sharing cognates with them all.

- English Historical lexicography and linguistics abound with severe etymological aberrances and implausible drawbacks for failing to show the phonetic, morphological, and semantic relationships amongst the above words.

$>$ Not all English and European words are cognates such as English merry and German murg 'short', which are actually different words that can nonetheless be traced back to Arabic cognates (Jassem 2018d).

$>$ Postulating Proto-Indo-European and Proto-Germanic roots as well as uncertain or unknown ones such as merry, more, mayor, umpire turns out to be a myth since Arabic can provide really living and true cognates for all words in those languages. For example, Proto-Germanic *murgijaz, which probably originally meant short-lasting', from PIE root *mergh-u- 'short', can't be cognates for merry 'happy' whose Arabic sources are more plausible and pertinent (see above). The same applies to more, major, much, and most which are wrongly derived from many whose Arabic sources are more pertinent and logical as has been clearly shown above.

$>$ The multiple meanings of English words besides the uncertainty of their origin such as mare 'young female horse; sea, water' is most likely the result of the lexical merger of two or more Arabic cognates which are the same or similar in both form and meaning: i.e., muhra 'young female horse' and mar 'water, sea' (see above).

$>$ The different spellings and forms of the above words may be due to 'bad' writing habits of early poorly educated scribes, typists, and printers (Campbell 2013: Chs. 1, 15; Pyles and Algeo 1993), linguistic variation and change, and/or lexical conditioning. One can also add the manipulation and/or fixation of language by early lexicographers and grammarians, a process called standardization.

In short, English and European languages cannot be satisfactorily and logically accounted for historically and genetically without Arabic which can be legitimately considered roll-free, deviant, or loose Arabic dialects.

\section{REFERENCES}

[1] Albaheth AlArabi: Qamoos Arabi. (2018). Retrieved http://www.baheth.info (December 10, 2018).

[2] Almaany.com. (2018). Retrieved http://www.almaany.com (December 10, 2018).

[3] Bergs, Alexander and Brinton, Laurel (eds). (2012). Handbook of English historical linguistics. Berlin: Walter de Gruyter.

[4] Campbell, L. (2013). Historical linguistics: An introduction. (3 ${ }^{\text {rd }}$ edn). Edinburgh: Edinburgh University Press.

[5] Crowley, T. (1997). An Introduction to historical linguistics. (3rd edn). Oxford: Oxford University Press.

[6] Harper, Douglas. (2001-2018). Online etymology dictionary. Retrieved http://www.etymonline.com (December 10, 2018).

[7] Ibn Manzoor, Abi Alfadl Almisri. (2018). Lisan al3arab. Beirut: Dar Sadir. Retrieved http://www. baheth.info (December 10, 2018). 
English and European Languages are Arabic Dialects on the Loose: The Evidence: "The Emperor Marries Mary Merrily on a Mare by the Mere": A Consonantal Radical Theory Approach

[8] Jassem, Zaidan Ali. (1987). Phonological variation and change in immigrant speech: A sociolinguistic study of a 1967 Arab-Israeli war immigrant speech community in Damascus, Syria. PhD Thesis, Durham University, UK. Retrieved http://etheses.dur.ac.uk/1682/1/1682.pdf (December 5, 2016).

[9] Jassem, Zaidan Ali. (2012a). The Arabic origins of numeral words in English and European languages. International Journal of Linguistics 4 (3), 225-41. Retrieved URL: http://dx.doi.org/10.5296/ijl.v4i3.1276 (December 5, 2016).

[10] Jassem, Zaidan Ali. (2012b). The Arabic origins of common religious terms in English: A lexical root theory approach. International Journal of Applied Linguistics and English Literature 1 (6), 59-71. Retrieved URL: http://dx.doi.org/10.7575/ijalel.v.1n.6p.59 (December 15, 2018).

[11] Jassem, Zaidan Ali. (2012c). The Arabic origins of English pronouns: A lexical root theory approach. International Journal of Linguistics 4 (4), 83-103. Retrieved URL: http://dx.doi.org/10.5296/ijl.v4i4.227 (December 15, 2018).

[12] Jassem, Zaidan Ali. (2012d). The Arabic origins of determiners in English and European languages: A lexical root theory approach. Language in India 12 (11), 323-359. Retrieved URL: http://www.languageinindia.com (December 15, 2018).

[13] Jassem, Zaidan Ali. (2012e). The Arabic Origins of Verb "To Be" in English, German, and French: A Lexical Root Theory Approach. International Journal of Applied Linguistics and English Literature 1 (7), 185-196. Retrieved URL: http://dx.doi.org/10.7575/ijalel.v.1n.7p.185 (December 15, 2018).

[14] Jassem, Zaidan Ali. (2012f). The Arabic origins of number and gender markers in English, German, French, and Latin: a lexical root theory approach. Language in India 12 (12), 89-119. Retrieved URL: http://www.languageinindia.com (December 15, 2018).

[15] Jassem, Zaidan Ali. (2013a). The Arabic origins of derivational morphemes in English, German, and French: A lexical root theory approach. Language in India 13 (1), 48-72. Retrieved URL: http://www.languageinindia.com (December 15, 2018).

[16] Jassem, Zaidan Ali. (2013b). The Arabic origins of negative particles in English, German, and French: A lexical root theory approach. Language in India 13 (1), 234-48. Retrieved URL: http://www.languageinindia.com (December 15, 2018).

[17] Jassem, Zaidan Ali. (2013c). The English, German, and French cognates of Arabic back consonants: A lexical root theory approach. International Journal of English and Education 2 (2): 108-128. Retrieved URL: http://www.ijee.org (December 15, 2018).

[18] Jassem, Zaidan Ali. (2013d). The Arabic origins of "water and sea" terms in English, German, and French: A lexical root theory approach. Language in India 13 (2): 126-151. Retrieved URL: http://www.languageinindia.com (December 15, 2018).

[19] Jassem, Zaidan Ali. (2013e). The Arabic origins of "air and fire" terms in English, German, and French: A lexical root theory approach. Language in India 13 (3): 631-651. Retrieved URL: http://www.languageinindia.com (December 15, 2018).

[20] Jassem, Zaidan Ali. (2013f). The Arabic origins of "celestial and terrestrial" terms in English, German, and French: A lexical root theory approach. International Journal of English and Education 2 (2): 323345. Retrieved URL: http://www.ijee.org (December 15, 2018).

[21] Jassem, Zaidan Ali. (2013g). The Arabic origins of "animal" terms in English and European languages: A lexical root theory approach. Language in India 13 (4): 68-106. Retrieved URL: http://www.languageinindia.com (December 15, 2018).

[22] Jassem, Zaidan Ali. (2013h). The Arabic origins of "body part" terms in English and European languages: A lexical root theory approach. International Journal of Current Applied Linguistics and English Literature (1). Retrieved URL: http://www.bretj.com (December 15, 2018).

[23] Jassem, Zaidan Ali. (2013i). The Arabic origins of "speech and writing" terms in English and European languages: A lexical root theory approach. Language in India 13 (5): 108-159. Retrieved URL: http://www.languageinindia.com (December 15, 2018).

[24] Jassem, Zaidan Ali. (2013j). The Arabic origins of "time words" in English and European languages: A lexical root theory approach. Language in India 13 (6): 274-97. Retrieved URL: http://www.languageinindia.com (December 15, 2018).

[25] Jassem, Zaidan Ali. (2013k). The Arabic origins of "family words" in English and European languages: A lexical root theory approach. International Journal of English and Education 2 (3): 261-77. Retrieved URL: http://www.ijee.org (December 15, 2018).

[26] Jassem, Zaidan Ali. (2013m). The Arabic origins of "cutting and breaking words" in English and European languages: A lexical root theory approach. Research Journal of English Language and Literature 1 (2): 155-68. Retrieved URL: http://rjelal.com (December 15, 2018). 
English and European Languages are Arabic Dialects on the Loose: The Evidence: "The Emperor Marries Mary Merrily on a Mare by the Mere": A Consonantal Radical Theory Approach

[27] Jassem, Zaidan Ali. (2013n). The Arabic origins of "movement and action words" in English and European languages: A lexical root theory approach. Research Journal of English Language and Literature 1 (3): 187-202. Retrieved URL: http://rjelal.com (December 15, 2018).

[28] Jassem, Zaidan Ali. (2013o). The Arabic origins of "perceptual and sensual words" in English and European languages: A lexical root theory approach. Research Journal of English Language and Literature 1 (4): 212-24. Retrieved URL: http://rjelal.com (December 15, 2018).

[29] Jassem, Zaidan Ali. (2013p). The Arabic origins of "cognitive and mental words" in English and European languages: A lexical root theory approach. International Journal of English and Education 2 (4): 65-83. Retrieved URL: http://www.ijee.org (December 15, 2018).

[30] Jassem, Zaidan Ali. (2013q). The Arabic origins of "love and sexual words" in English and European languages: A lexical root theory approach. International Journal of Language and Linguistics 1 (4): 97114. Retrieved URL: http://www.ijll.org (December 15, 2018).

[31] Jassem, Zaidan Ali. (2014a). The Arabic origins of "wining and dining words" in English and European languages: A lexical root theory approach. International Journal of English and Education 1 (4): 146-74. Retrieved URL: http://www.ijee.org (December 15, 2018).

[32] Jassem, Zaidan Ali. (2014b). The Arabic origins of "question and auxiliary words" in English and European languages: A lexical root theory approach. International Journal of Language and Linguistics 2 (1). Retrieved URL: http://www.ijll.org (December 15, 2018).

[33] Jassem, Zaidan Ali. (2014c). The Arabic origins of "prepositions and conjunctions" in English and European languages: A lexical root theory approach. Journal for the Study of English Linguistics 2 (1). Retrieved URL: http://www.jsel.org (December 15, 2018).

[34] Jassem, Zaidan Ali. (2014d). Translating cultural universals radically: A lexical root theory approach for translating English, French, and German cultural terms into Arabic. In الترجمة وإثكالات المثاقفة: بحوث (Proceedings of the International Conference on Translation and the Problematics of Cross-Cultural Understanding, the Forum for Arab and International Relations, Doha, Qatar 26-27 February 2014: 643-695, 505-60).

[35] Jassem, Zaidan Ali. (2014e). The Arabic origins of "divine and theological terms" in English, German, and French: A lexical root theory approach. Language in India 14 (3): 155-195. Retrieved URL: http://www.languageinindia.com (December 15, 2018).

[36] Jassem, Zaidan Ali. (2014f). The Arabic origins of "proper names" in English and European languages: A lexical root theory approach. Research Journal of ELT and Poetry 2 (2): 201-22. Retrieved URL: http://www.journalofelt.in (December 15, 2018).

[37] Jassem, Zaidan Ali. (2014g). The Arabic origins of "mathematical and computational terms" in English and European languages: A lexical root theory approach. International Journal on Studies in English and Literature 2 (5): 21-40. Retrieved URL: http://www.arcjournals.org/ijsell (December 15, 2018).

[38] Jassem, Zaidan Ali. (2014h). The Arabic origins of "Mandarin Chinese Pronouns": A radical linguistic theory approach. International Journal of English and Education 3 (3). Retrieved URL: http://www.ijee.org (December 15, 2018).

[39] Jassem, Zaidan Ali. (2014i). The Arabic origins of "Finnish and Basque Pronouns": A radical linguistic theory approach. Journal of English language and literature 2 (1): 109-20. Retrieved URL: http://www.jellonline.com (December 15, 2018).

[40] Jassem, Zaidan Ali. (2014j). The Arabic origins of English and Indo-European "colour and artistic terms": A radical linguistic theory approach. International Journal of English language, literature, and Translation 1 (1): 1-14. Retrieved URL: http://www.ijels.com (December 15, 2018).

[41] Jassem, Zaidan Ali. (2014k). I buy, Ich kaufe, \& J'achéte as Arabic Dialectal Variants: A radical linguistic theory approach. International Journal of language and linguistics 2 (5): 317-27. Retrieved URL: http://www.sciencepublishinggroup.com/ijll. Doi: 10.11648/j.ijll.20140205.15 (December 15, 2018).

[42] Jassem, Zaidan Ali. (2015a). The Arabic origins of English and Indo-European "life and death terms": A radical linguistic theory approach. International Journal of English and Education 4/1: 322-345. Retrieved URL: http://www.ijee.org (December 15, 2018).

[43] Jassem, Zaidan Ali. (2015b). Towards a radical translation theory for names: A comparative historical linguistics approach. International Journal of English and Education 4/1: 298-321. Retrieved URL: http://www.ijee.org (December 15, 2018).

[44] Jassem, Zaidan Ali. (2015c). The Arabic origins of English and Indo-European "medical terms": A radical linguistic theory approach. Journal of English Language and Literature 2/1: 18-47. Retrieved URL: http://www.joell.in (December 15, 2018). 
English and European Languages are Arabic Dialects on the Loose: The Evidence: "The Emperor Marries Mary Merrily on a Mare by the Mere": A Consonantal Radical Theory Approach

[45] Jassem, Zaidan Ali. (2015d). The Arabic origins or cognates of English and Indo-European "case markings and word order": A radical linguistic theory approach. Language in India 15/3: 104-40. Retrieved URL: http://www.languageinindia.com (December 15, 2018).

[46] Jassem, Zaidan Ali. (2015e). The Arabic origins of English and Indo-European "democratic terms": A radical linguistic theory approach. Journal of English Language and Literature 2/2: 111-139. Retrieved URL: http://www.joell.in (December 15, 2018).

[47] Jassem, Zaidan Ali. (2015f). The Arabic origins of English and Indo-European "military terms": A radical linguistic theory approach. Language in India 15/5: 105-139. Retrieved URL: http://www.language inindia.com (December 15, 2018).

[48] Jassem, Zaidan Ali. (2015g). The Arabic origins of English and Indo-European "legal terms": A radical linguistic theory approach. Journal of Applied Linguistics and Translation 1/1: 10-29. Retrieved URL: http://www.languageinindia.com (December 15, 2018).

[49] Jassem, Zaidan Ali. (2015i). The Arabic origins of English and Indo-European "urban terms": A radical linguistic theory approach. English Review: Journal of English Education 3/2: 146-166. Retrieved URL: http://www.journal.uniku.ac.ind/index.php/ERJEE (December 15, 2018)

[50] Jassem, Zaidan Ali. (2015j). Negation in world languages: A radical linguistic theory approach. Veda's Journal of English Language and Literature 2/4: 1-17. Retrieved URL: http://www.joell.in (December $15,2018)$

[51] Jassem, Zaidan Ali. (2016a). The Arabic origins of "plural markers" in world languages: A radical linguistic theory approach. International Journal of English and Education 5/1: 193-223. Retrieved URL: http://www.ijee.org (July 30, 2016). (Also in Indonesian EFL Journal 1 (2): 144-163, 2015.)

[52] Jassem, Zaidan Ali. (2016b). The Arabic origins of English and Indo-European "floral terms": A radical linguistic theory approach. International Journal on Studies in English and Literature 4 (2): 81-99. Retrieved URL: http://www.arcjournals.org/ijsell (December 15, 2018).

[53] Jassem, Zaidan Ali. (2016c). The Arabic origins of English and Indo-European "fashion and modeling terms": A radical linguistic theory approach. International Journal on Studies in English and Literature 4 (6): 40-60. Retrieved URL: http://dx.doi.org/10.20431/2347-3134.0405007 (December 15, 2018).

[54] Jassem, Zaidan Ali. (2016d). The Arabic origins of English and Indo-European "definite articles": A radical linguistic theory approach. International Journal of English Language, Literature and Humanities 4/6: 530-55. Retrieved URL: http://www.ijellh.com/wp-content/uploads/2016/06/64.-Zaidan-Ali-Jassempaper-final.pdf?cec.7d6 (December 15, 2018)

[55] Jassem, Zaidan Ali. (2016e). English, German, French, Latin, Greek, and Sanskrit are entirely ArabicFree Good Lovely Comely Merry Beautiful Girls Marry Noble Villains in Wedding and Engagement Rings Ceremoniously: A radical linguistic theory approach. International Journal of English and Education 5/3: 335-56. Retrieved URL: http://www.ijee.org/yahoo_site_admin/assets/docs/26.19215751 .pdf (December 15, 2018)

[56] Jassem, Zaidan Ali. (2016f). The Arabic origins and development of English, German, and French: A radical linguistic theory approach. Proceedings of $9^{\text {th }}$ International Conference on Allugha Alarabia asas althaqafa alinsania 'Arabic as the Basis of Human Culture' Vol. 1. University of Jakarta in Cooperation with The University of Science and Technology of Jordan, and Indonesia's Arabic Teachers' Association, Jakarta, Indonesia, 9-10 August 2016, pp. 363-404.

[57] Jassem, Zaidan Ali. (2016g). Vocabulary learning and teaching: A radical linguistic theory approach. Proceedings of $10^{\text {th }}$ International Conference on Arabic Language and Culture in Inter-Continental Educational Institutions (PINBA X IMLA), Vol. 1. The State Institute of Islamic Studies Pontianak in Cooperation with Arabic Teachers' Association of Indonesia, West Kalimantan, Indonesia, 26-28 August 2016, pp. 50-70.

[58] Jassem, Zaidan Ali. (2016h). Campbell's (2013) Historical linguistics: An introduction: A critical review. International Journal of English Language, Literature and Humanities 10/6: 530-55. Retrieved URL: http://www.ijellh.com/wp-content/uploads/2016/06/64.-Zaidan-Ali-Jassem-paper-final.pdf?cec.7d6 (December 15, 2018)

[59] Jassem, Zaidan Ali. (2016i). Medical Translation: A Radical Linguistic Theory Approach. Paper presented at presented الترجة وإثكالات المثاقفة International Conference on Translation and the Problematics of Cross-Cultural Understanding), the Forum for Arab and International Relations, Doha, Qatar 12-13 December 2016.

[60] Jassem, Zaidan Ali. (2017a). Harper's Etymology Dictionary Online (etymonline): A critical review. International Journal of English and Education 6/1: 335-56. Retrieved URL: http://www.ijee.org/yahoo_ site_admin/assets/docs/26.19215751.pdf (December 15, 2018) 
English and European Languages are Arabic Dialects on the Loose: The Evidence: "The Emperor Marries Mary Merrily on a Mare by the Mere": A Consonantal Radical Theory Approach

[61] Jassem, Zaidan Ali. (2017b). Myth and Fallacy in the Oxford English Dictionary: A Critique with Reference to "That Girl Marries the Villain". Veda's Journal of English Language and Literature 4/1: 4255. Retrieved URL: http://www.joell.in (July 3, 2017)

[62] Jassem, Zaidan Ali. (2018a). The Arabic origins or cognates of negative terms in world languages: A radical linguistic theory approach. International Journal of English and Education 7/1: 124-52. Retrieved URL: http://www.ijee.org/yahoo_site_admin/assets/docs/10.5125350.pdf (December 15, 2018)

[63] Jassem, Zaidan Ali. (2018b). The Arabic origins or cognates of names of "Week Days" in English and European Languages: A lexical root theory approach. International Journal of English and Education 7/2: 273-94. Retrieved URL: http://www.ijee.org/yahoo_site_admin/assets/docs/10.5125350.pdf (December $15,2018)$

[64] Jassem, Zaidan Ali. (2018c). The Arabic origins or cognates of English and European place names: A consonantal radical theory approach. Indian Journal of Arts 8: 90-102. Retrieved URL: http://www.discoveryjournals.org/arts/current_issue/2018/A11.pdf (December 15, 2018)

[65] Jassem, Zaidan Ali. (2018d). The Arabic origins of "Sex Derivatives and Formally Similar Terms Six, Sack, Sake, Suck, Seek, Soak, Kiss, Case, Cozy" in English and European place names: A consonantal radical theory approach. International Journal on Studies in English and Literature 6 (10): 41-52. Retrieved URL: http://dx.doi.org/10.20431/2347-3134.0610005 (December 15, 2018).

[66] Mu3jam alama3ani (2016). Retrieved URL: http://www.almaany.com (December 15, 2018).

[67] Pyles, T. and J. Algeo. (1993). The origins and development of the English language. (4th edn). San Diego: HBJ.

[68] Yule, G. (2014). The study of language. ( $5^{\text {th }}$ ed). Cambridge: Cambridge University Press.

Citation: Zaidan Ali Jassem. "English and European Languages are Arabic Dialects on the Loose: The Evidence: "The Emperor Marries Mary Merrily on a Mare by the Mere": A Consonantal Radical Theory Approach "International Journal on Studies in English Language and Literature (IJSELL), vol 7, no. 1, 2019, pp. 30-42. doi: http://dx.doi.org/10.20431/2347 -3134.0701004.

Copyright: (C) 2019 Authors. This is an open-access article distributed under the terms of the Creative Commons Attribution License, which permits unrestricted use, distribution, and reproduction in any medium, provided the original author and source are credited. 